\title{
BİTKİ SAĞLIĞININ SÜRDÜRÜLEBİLİR TARIMDAKİ YERİ
}

\author{
Importance of Plant Health in Sustainable Agriculture
}

Doç. Dr. Birol AKBAŞ

*Sorumlu Yazar:

birol.akbas@tarimorman.gov.tr

T.C. Tarım ve Orman Bakanlığı, Bitkisel Üretim Genel Müdürlügüu, Ankara

ORCID (Yazar Sırasına Göre):

0000-0001-9797-7536

Gönderilme Tarihi: 19 Ağustos 2019

Kabul Tarihi ～: 23 Ekim 2019

\section{ÖZET}

Bitki sağlığı sürdürülebilir tarım ve ormancılığın yanında biyoçeşitliliğin ve ekosistemin korunması açısından küresel bir öneme sahiptir. Tarımsal ürünlerin g1da güvenliğine uygun ve kaliteli bir şekilde üretiminde bitki sağlığ 1 hayati bir rol oynar. Hayvan beslenmesi, doğal kaynakların devamlılığı, süs ve peyzaj anlamında da çok önemlidir. Günümüzde artan küresel ticaret ve iklim değişikliğinden dolayı zararlı organizmaların yayılışı ve hareketi çok daha geniş alanlara ulaşmıştır. $\mathrm{Bu}$ da sürdürülebilir tarım açısından zararlı organizmaların oluşturduğu negatif etkileri geçmişe göre çok daha fazla önemli kılmaktadır.

Anahtar Kelimeler: Zararlı organizma, Tarımsal üretim, Gıda güvenliği, Ekoloji, Biyoçeşitlilik

\begin{abstract}
Plant health has global importance for sustainable agriculture and forestry as well as protection of biodiversity and ecosystems. It plays vital role for production of sustainable and profitable crops to food security. It has also extreme importance for ornamentals, natural resources and animal feed. Nowadays, movement and spread of plant pests are reaching in wide range areas around the world
\end{abstract}


because of increasing global trade and changing climate. This makes their negative impacts on sustainability of agriculture more considerable than ever before.

Keywords: Harmful organisms, Agricultural production, Food security, Ecology, Biodiversity

\section{GİRIŞ̧}

Sağladıkları oksijen ile bitkiler yeryüzündeki bütün hayatın temelini oluşturur ve insan besininin \%80'den fazlasını karşılar. Tarımda rüzgâr hızını azaltarak, erozyon, sel vb. gibi birçok doğal afetin önüne geçerek doğal çevreyi korur ve zenginleştirirler. Şehir hayatında ise gürültünün azalmasına yol açıp, gölge ve güzel alanlar sağlayarak yaşamı kolaylaştırır ve güzelleștirirler.

Bitkiler gıda güvenliği açısından önemli olduğu kadar, insanoğlunun aktif ve sağlıklı yaşaması için de kolaylıkla erişilebilir, güvenilir ve besleyici olmalıdırlar. Tarladan hasat sonrasına kadar biyotik ve abiyotik birçok çeşitli faktörden olumsuz olarak etkilenmektedir. Bitki sağlığı; hastalık, zararlı ve yabancı otlar gibi biyotik etmenlerin yanında diğer abiyotik nedenlerden kaynaklanan kayıpları azaltmak için çevre dostu, ekonomik ve etkili yöntem ve stratejiler geliştiren bir bilim dalıdır. Genellikle zararlı organizmaların mücadelesi, özellikle de ticareti sırasında yeni bölgelere girişinin engellenmesinde kullanılan tedbirler dizisi ile ilgili bir disiplin olarak düşünülür. $\mathrm{Bu}$ yöntem ve stratejileri geliştirirken, insan sağ lığ doğal denge ve biyoçeşitliliğin korunması esastır.
Zararlı organizmalar bir kere geniş bir bölgeye yerleştikten sonra bunların bertaraf edilmesi çok güçtür. Bitki zararlı ve hastalıkları ürünlerde de zarar oluşturabildiğinden, gida güvenliği açısından bir tehdit oluşturur. $\mathrm{Bu}$ nedenle ulaşılabilirliğinin azalmasına ve gıda fiyatlarının artmasına yol açar. Bitki zararlı ve hastalıkları toplumların geleneksel gida tercihlerinde de değișikliğe yol açabildiklerinden gidanın lezzet kalitesini de negatif olarak etkiler.

Dolayısıyla bitki sağlığı gıda güvenliği, çevre ve biyoçeşitliliğin korunması açısından küresel bir öneme sahiptir. Bunlar da sürdürülebilir tarımın en önemli unsurlarıdır. Günümüzde bitki sağlığı ile ilişkili yaklaşımların genişlemesi, çevre koruma ve sürdürülebilirlik gerekliliğinin artmış olması, tüm dünyada alarm seviyelerine ulaşan biyoçeşitliliğin azalması ve küresel nüfus artışından dolayı bitki sağlığının önemi daha da artmıştır. Bu önemin fark edilmesini sağlamak amaciyla FAO, 39. konferansinda 2020 y1l "Uluslararası Bitki Sağlığı" yılı olarak ilan edilmiştir. Böylelikle açlık, fakirlik, çevreyi tehdit eden unsurlar ve ekonomik gelişmeyi de içeren küresel konular içerisinde bitki sağlı̆̆ının rolü ve etkilerinden tüm paydaşların ve politika belirleyicilerin haberdar olması amaçlanmıștır. Bununla birlikte sürdürülebilir tarımın devamlılı̆̆ı, küresel gıda güvenliği, çevre ve biyoçeşitliliğin korunmasının sağlanması hedeflenmiştir. $\mathrm{Bu}$ çalışmada, bitki sağlı̆̆ının sürdürülebilir tarımdaki yeri ve önemi ile birlikte ülkemizdeki durumu değerlendirilmiştir.

\section{Bitki Sağlığının Önemi}

Bitki zararlı ve hastalıkları ekonomik, ekolojik, 
çevresel, insan ve diğer faunaların sağlığı açısından çok geniş bir negatif etkiye sahip olduğundan dolayı yol açtıkları zararın gerçek maliyetini hesaplamak çok zordur. Ancak üründe meydana getirdikleri kayıplar ve de bunların mücadelesinde harcanan zaman ve para endirekt zarar olarak gözükmektedir.

Bitki zararlı ve hastalıklarının sebep olduğu salgınlar yıllarca çok büyük gıda noksanlığına ve kıtlıklara sebep olmuştur. Patates mildiyösü hastalığından dolayı (Phytophthora infestans) İrlanda'da (1845-1846) milyonlarca insan açlik çekmiş ve bir milyondan fazla insan hayatını kaybetmiş ve 1,5 milyon insan evini terk etmek zorunda kalarak Amerika’ya göç etmek zorunda kalmıştır. Turunçgil kanseri hastalığ1 (Xanthomonas citri) Asya, Afrika, Brezilya ve ABD'de 1910 yıllarında ve daha sonrasında görülmüş, milyonlarca ağaç imha edilmiştir. Tristeza hastalığı, 1910 yılında Afrika'da, 1950 yılında Amerika' da epidemi yapmış milyonlarca turunçgil ağacının kesilmesine neden olmuştur. Çeltik kahverengi lekesi hastalığı (Bipolaris oryzae, syn. Helminthosporium oryzae) Hindistan ve Bangladeş'de 1942-1943 yılında yapmış olduğu salgında üründe \%50-90 oranında zarara neden olarak kıtlığa ve sonuçta da 2 milyon insanın ölümüne neden olmuştur. $\mathrm{Bu}$ ülkelerde bu hastalıkların yol açtığı yıllık ekonomik kayıp 100 milyar ABD doları olarak hesaplanmıştır.

Bunlara ilaveten, Kore Cumhuriyetinde, 10 milyondan fazla ağaç Çam solgunluk nematodu (Bursaphelenchus xylophilus) enfeksiyonundan dolayı kaybedilmiştir (FAO, 2019).
Ayrıca, tahıllarda özellikle de çavdarda hastalık yapan Çavdar mahmuzu hastalığının (Claviceps purpurea) oluşturduğu ergotların neden olduğu toksisiteden dolayı 11. yüzyıldan 20. yüzyılın ortalarına kadar binlerce insan ve hayvan zarar görmüştür. Bununla ilgili olarak Avrupa (Fransa, İngiltere, Rusya) ve Afrika (Etiyopya)'da binlerce insan ve çok daha fazla hayvanın (at, besi hayvanları ve hindi vb.) sakat kaldığına ve öldüğüne dair kayıtlar mevcuttur (Agrios, 2005). Ülkemizde ise 1914 yılında yaşanan çekirge (Dociostaurus maroccanus) salgını sonucu hububat alanları büyük zarar görmüş, açlık tehlikesiyle karşılaşılmıştır.

Bitki zararlı ve hastalıkları küresel gıda üretiminin hasat sonrası kayıplarla birlikte \%40-45'lere varan kaybından sorumludur. Ürün kaybının yıllık değeri de yaklaşık 550 milyar ABD dolarıdır (Agrios, 2005). FAO (2019) bitki sağlığından dolayı olan ticari kaybın değerinin yıllık 220 milyar ABD doları olduğunu belirtmiştir. Amerika'da ise yıllık ürün kaybı 23 milyar ABD doları olarak hesaplanmıştır. Ülkemiz için ise bu organizmalarla mücadele edilmediği taktirde oluşabilecek zararın boyutu bitkisel üretimin en az 1/3'üne zarar vereceği hesap edilirse 10 milyar ABD dolarına kadar ulaşılabilecektir. Bu kayıpları engellemek için dünyada 3,5 milyon ton pestisit kullanılmakta, bunun parasal değeri de 45 milyar ABD dolarıdır (Agrios, 2005). Ülkemizde ise zararlı organizmalara karşı kullanılan pestisitlerin yıllık maliyeti yaklaşık 350 milyon ABD doları olarak hesaplanmıştır (Burçak ve ark., 2015). Yalnız zararlı organizmaların olumsuz etkisini gidermek için kullanılan pestisitlerin maddi 
boyutu yanında doğal çevreye ve canlılara verdiği olumsuz etkiler de ayrı bir muamma olarak karşımıza çıkmaktadır.

Bir bölgeye yeni girmiş olan hastalık ve zararlıların potansiyel olarak temel bitkisel ürünleri tehdit etme ihtimali vardır. Örnek vermek gerekirse Patates böceği olarak bilinen, Leptinotarsa decemlineata, patatesleri şiddetli bir şekilde etkileyen bir zararlıdır. Çin'de 2015 yılında temel gıda olarak patates yetiştiriciliğine geçilmesi planlanmış, ancak patates üretimi Patates böceğinin artan tehdidi ile karşı karşıya kalmış ve 3,2 milyon ABD doları kayba yol açmıştır. Bununla birlikte, Patates böceği Solanaceae familyasından domates ve patlıcan gibi bitkilerde de aynı şekilde zarar oluşturabilir. Demokratik Kongo Cumhuriyeti ve Ruanda çiftçisinin gelirinin sırasıyla \%90 ve \%60-80'ni karşılayan muz üretimi ne yazık ki Panama hastalığı olarak da bilinen muz fusarium solgunluğu Fusarium oxysporum f. sp. cubense tropikal 1rk 4 tarafından ciddi bir biçimde tehdit altındadır. Bu ülkelerde muz üretiminde zararlılardan kaynaklanan herhangi bir azalma g1da güvenliği ve yaşam üzerinde ciddi olumsuz etkilere sahiptir.

Bactrocera dorsalis Asya kıtasına özgü bir meyve sineğidir ancak şimdi en az 65 ülkede bulunmuştur. Afrika'da, 2003 yılında tespit edilmiştir ve bölgedeki ciddi avakado, muz, guava ve mango ticaretinden dolayı zararlının sahip olduğu tehdit, büyük bir bitki sağlığ1 mücadelesini ortaya koymuştur. Bölgedeki ticaret kısıtlamalarından dolayı yıllık kaybın 2 milyar ABD dolarına ulaştığı düşünülmektedir.
Diğer bir örnek Rhynchophorus ferrugineus, bilinen adıyla Palmiye kırmızı böceği (red palm weevil), palmiye ve hurmada çok ciddi kayıplara yol açan ve de Orta Doğu ve Akdeniz havzasında vaha ekosisteminde gıda güvenliği açısından tahripkar etkilere sahip bir zararlıdır (FAO, 2017).

Uganda' da 1999 yılında ilk kez saptanan Buğday kara pas1 (Puccinia graminis f. sp. tritici)'nın Ug99 1rkı tüm dünyada özellikle de buğday alanları için çok ciddi bir tehlike oluşturmuştur. Bu 1rkın 2000'li y1llardan itibaren Afrika'nın dışına çıkıp Yemen ve İran'a çok hızlı bir şekilde ulaşması bütün ulusal ve uluslararası bitki sağlı̆̆ kuruluşlarını harekete geçirmiştir.

Biraz daha geriye gidecek olursak 1970-71 yıllarında, Güney mısır yaprak yanıklığı hastalığı (Southern corn leaf blight) ABD'de önemli ekonomik kayıplara neden olmuştur. Eşeysiz dönemi Bipolaris maydis olan, Cochliobolus heterostrophus'un T-1rk1 nın neden olduğu bu hastalık ABD'de mısır yetiştirilen alanların \%15'inde zarar oluşturarak, yaklaşık 1 milyar ABD doları zarara yol açmıştır (Bruns, 2017). Tomato yellow leaf curl virus 1960'l1 y1llardan itibaren Akdeniz ülkelerinde ve sonrasında Orta Amerika'da, özellikle de 1980'li yıllardan itibaren ekonomik zarara yol açmıştır (Caciagli, 2007). Plum pox potyvirus'un sert çekirdekli meyvelerde neden olduğu Şarka hastalığı 1915 yılında ilk kez Bulgaristan'da saptandıktan sonra, Güneydoğu ve Orta Avrupa'dan sonra da tüm dünya sert çekirdekli meyve üretimini ekonomik anlamda tehdit edip, yüz binlerce sert çekirdekli meyve ağacının kesilmesine neden 
olarak ciddi ekonomik kayıplara yol açmıştır.

Aynı şekilde birçok bitkide (asma, turunçgil, şeftali, erik, zeytin, badem, kahve, zakkum, pekan cevizi, yaban mersini ve bazı orman ağaçlarında) ekonomik önemde hastalığa yol açan Xylella fastidiosa için ülkemizin de üyesi olduğu Avrupa ve Akdeniz Bitki Koruma Organizasyonu (EPPO)'nun A2 karantina listesinde yer almasına rağmen oluşturabileceği ekonomik kayıptan dolayı bu organizma için özel bir alarm statüsü oluşturulmuştur.

Bitki zararlı ve hastalıklarının meydana getirdiği bütün bu ekonomik kayıpların yanında, en önemli zararlarından biri de istilacı türlerden dolayı biyoçeşitliliğin azalmasına yol açarak ekosisteme verdiği zarardır. Gıda güvenliği açısından ise bitki zararlı ve hastalıkları küresel ticaretin bu organizmaların doğal ortamından hareket etmesini sağlayarak değiştirmesinden ve iklim değişikliğinin bu organizmalara daha uygun şartlar sağlamasından çok daha büyük bir tehdide sahiptir. Artan nüfusun yanında, iklim değişikliği ve artan enerji ihtiyacından dolayı 2050 yılına kadar tarımsal üretimin şimdi üretilenden \%50 daha fazlasını üretmek gerekmektedir. Bütün bunlar ve artan küresel ticaret bitki sağlığını daha da önemli kılmaktadır.

\section{Bitki Sağlığının Tarımımızdaki Yeri}

Ülkemizde 1914 yılında yaşanan çekirge (Dociostaurus maroccanus) salgınından dolayı 7 Mart 1916 tarihinde Bitki Sağlığı ile ilgili ilk yasa, "Çekirge Kanunu" ismi altında çıkarılmıştır. Zirai mücadele hizmetleri 1924 yılında "Ziraat Vekaleti" adı ile kurulmuş olan
Tarım Bakanlığı bünyesinde yer alan Ziraat Umum Müdürlüğü'ne bağlı 'Zirai Mücadele Şubesi Müdürlüğü tarafindan yürütülmeye başlanmıştır. Zirai mücadele öğretimine ise 1928 yılında Halkalı Yüksek Ziraat Okulunda tarımsal öğretiminin başladığı 1846 yılından tam 82 y1l sonra geçilmiştir.

Tahıl alanlarımızın en önemli zararlısı olan süneye karşı 1928 yılında devlet mücadelesi yürürlüğe konmuş ve daha sonraları 1936 yılında 'Nebatları Hastalık ve Zararlı Böceklerden Koruma Kanunu" çıkarılmıştır. Hastalık, zararlı ve yabancı otlardan kaynaklanan ürün kayıplarının öneminin fark edilmesiyle 1950'li yıllarda Zirai Mücadele kuruluşlarının daha da genişletilmesi ihtiyacı ortaya çıkmıştır. Bunun sonucunda 1957 tarihinde 'Zirai Mücadele ve Zirai Karantina Umum Müdürlüğü” kurulmuş, zirai mücadele hizmetleri de Ziraat Umum Müdürlüğünden alınarak bu kuruluşa verilmiştir. Ülkemizde zirai mücadele faaliyetleri uzunca bir süre aynı yıl çıkarılan 6968 sayılı Zirai Mücadele ve Zirai Karantina Kanunu ve bu kanuna bağlı yönetmeliklerle düzenlenmiştir. 1957 yılında çıkarılan kanun ve bu kanuna bağlı yönetmelikler 1980 yılına kadar hiçbir değişiklik yapılmadan yürürlükte kalmıştır.

Zirai Mücadele ve Zirai Karantina Genel Müdürlüğü 1979 yılında yeniden yapılanmıştır. 18.06.1984 tarih ve 18435 Sayılı Resmi Gazetede yayınlanan '212 sayıl1 Kanun Hükmünde Kararname" ile Tarım Bakanlığı yeni bir yapılanmaya tabi tutulmuştur. Zirai Mücadele ve Karantina Genel Müdürlüğü kapatılarak bütün görevleri, Koruma ve Kontrol Genel Müdürlüğü 
bünyesinde toplanmıştır.

Tarım ve Köyişleri Bakanlığının (TKB) teşkilat yapısı 07.8.1991 tarihinde çıkartılan bir kanun hükmünde kararname (KHK) ile yeniden düzenlenmiş ve 09.08.1991 tarihinde resmi gazetede yayımlanan 441 sayılı bu KHK ile Tarımsal Araştırmalar Genel Müdürlüğü ana hizmet birimi olarak kurulmuştur. Bu kararname ile Bakanlık araștırma organizasyonu merkez ve taşra olmak üzere iki bölümden oluşturulmuştur. Bitki sağlığı araştırmaları ile ilgili birimler 1991 yılında kurulan Tarımsal Araştırmalar Genel Müdürlüğü (şimdiki adı Tarımsal Araştırmalar ve Politikalar Genel Müdürlüğü) bünyesinde müstakil bir Daire Başkanlığı olarak, uygulama ile ilgili birimleri ise Koruma Kontrol Genel Müdürlüğü (şimdiki adı Gida ve Kontrol Genel Müdürlüğü) 'nün bünyesinde iki Daire Başkanlığı altında yer almıştır.

Bitki sağlığı hizmetleri 13.06.2010 tarihinde çıkarılan 5996 sayılı Veteriner Hizmetleri, Bitki Sağlığı, Gida ve Yem Kanunu'na göre yürütülmeye başlamıştır. Bakanlığımız 2011'de bir reorganizasyona daha gitmiş, Gıda, Tarım ve Hayvancılık Bakanlığının 03.06.2011 tarihli 639 sayılı Teşkilat ve Görevleri Hakkında Kanun Hükmünde Kararnameye dayanılarak Tarımsal Araştırma Enstitüleri ve İstasyonları Görev Yönergesi çıkarılmıştır. Bu yönergeyle bitki sağlı̆̆1 araştırma önceliklerine göre enstitülerimize görev verilmiştir.

Bakanlığımızın bitki sağlığı stratejisi ve önceliklerinde ana amaç; kültür bitkilerine arız olan zararlı organizmalar ile mücadelede, modern metot ve tekniklerin kullanılarak daha bol, kaliteli ve pestisit kalıntısı bulunmayan ürün elde edilmesini sağlamak ve sonuçta üreticinin gelirini arttırmak, zorunlu olmadıkça kimyasal ilaç kullanmamak veya çevre dostu ilaçları tercih etmek, bunları en uygun zamanda ve dozda kullanmak suretiyle zirai mücadele girdilerini azaltmak; pestisitlerin doğal dengeyi bozması, insan ve sicakkanlılara olumsuz etkisi, çevre kirlenmesi, ürünlerde kalıntı bırakması ve zararlılarda direnç oluşturması gibi olumsuz etkilerini en aza indirmek; hastalıklardan temiz üretim materyali elde etmek; zirai karantina tedbirlerini belirleyerek Türkiye'de bulunmayan zararlıların her türlü bitki ve tohumlarla ülkemize girmesini engellemek; girmiş olanların yayılmalarını önlemek ve en iyi şekilde mücadele etmek için gerekli araştırmaları yaparak, ülke ekonomisine ve bilime katkıda bulunmaktır.

$\mathrm{Bu}$ politika ve stratejide, entegre mücadele, biyolojik mücadele, biyoteknik mücadele, genetik mücadele, kültürel tedbirler, fiziksel ve mekanik mücadele, dayanıklı bitki materyali elde edilmesi, tahmin ve erken uyarı, çevre ve ekolojik tarım ile ilgili araştırmalara öncelik verilmektedir. Kimyasal mücadele araştırmalarında ise çevre dostu pestisitler (yeşil ya da ekolojik), böcek gelişimi düzenleyicileri, madeni ve bitkisel yağlar, pestisitlerin bitkisel ürünler, toprak ve sulardaki kalıntıları ile toksikolojik ve ekotoksikolojik araştırma ve uygulamalara öncelik verilmektedir.

Ülkemiz aynı zamanda bitki sağlığı ile ilgili uluslararası kuruluşlara üye olup, faaliyetlerine bu kuruluşların belirlediği kural, standart ve 
mevzuatlara göre yön vermektedir. Bölgesel bir bitki koruma organizasyonu olan ve 1951 yılında kurulan Avrupa ve Akdeniz Bitki Koruma Organizasyonuna (EPPO) 1965 y1lında üye olmuştur (01.07.1965 tarih ve 6/4713 sayılı Resmi Gazete). Bu üyelik 1969 yılında (20.06.1969 ve 13228 sayılı Resmi Gazete) yenilenmiştir.

FAO tarafindan tarımsal anlamda uluslararası ticaretin kolaylaştırılması ve bitki zararlı organizmalarının yayılmasının önlenmesi ve bu alanda kontrol önlemlerinin geliştirilmesi amacıyla Uluslararası Bitki Koruma Konvansiyonunun (IPPC ) sekreterliği 1951 kurulmuş ve 1952 yılında yürürlüğe girmiştir. Ülkemiz de bu antlaşma metnini 29 Temmuz 1988 tarihinde imzalayarak üye ülkelerden biri olmuştur. Antlaşma metni 1997 yılında revize edilmiş ve üye ülkelerin 2/3'nin onayının alındığ 2 Ekim 2005 tarihinden itibaren tekrar yürürlüğe girmiştir.

Ülkemiz Nisan 1994 yılında kurulan Dünya Ticaret Örgütüne (DTÖ) Mart 1995 tarihinden itibaren kurucu üye olarak dahil olmuştur. Bitki sağlığ1 yönünden bu örgütün belirlediği kurallara göre de hareket etmekle birlikte her daim AB mevzuatlarını baz almıştır. AB'ye uyum çerçevesinde bitki sağlığı ile ilgili mevzuat ve direktiflerin uyum çalışmalarına 2004 yılından itibaren hız verilmeye başlanmıştır. $\mathrm{Bu}$ çerçevede AB'nin bitki sağlıği ile ilgili 2000/29 direktifi esas alınarak, bazı mevzuatları kısmen özellikle de bazı spesifik zararlı organizmalar ile ilgili olanları da tamamen uyumlaştırılmıştır.

\section{SONUÇ}

Artan küresel nüfusu beslemenin en önemli unsuru sürdürülebilir tarımdır. Esası sürdürülebilir ekosisteme dayalı olan gıda güvenliği için bitki kaynakları korunmalı ve etkin hale getirilmelidir. Bunu sağlamanın en önemli yollarından biri de bitki sağlığıdır. $\mathrm{Bu}$ yüzden bitki sağlığı desteklenmeli ve önemini arttırıcı faaliyetlerde bulunulmalıdır. Yetkililer, sivil toplum kuruluşları, hatta bütün özel ve resmi tüm paydaşlar bir araya gelerek bitki sağlığından kaynaklanan g1da güvenliğini emniyete alarak önemli bir rol oynayabilirler. $\mathrm{Bu}$ bağlamda uluslararası düzeyde Temmuz 2017 yılında yapılan FAO Konferansında karara bağlanan taslak Birleşmiş Milletlerin genel toplantısında onaylanarak, 2020 yılı "Uluslararası Bitki Sağlığı Yılı (the International Year of Plant Health, IYPH)" olarak ilan edilmiştir.

Yetkililer bitki sağlığı ile ilgili yenilenen ulusal ve uluslararası standartları yürürlüğe koymada hevesli olmalı ve bunları teşvik etmelidirler. Sivil toplum kuruluşları ve diğer tüm paydaşlar buna destek olmalıdırlar. İnsanlar seyahatleri sırasında ülke içindeki farklı bölgelerden ve yurtdışından getirilen bitki, meyve ve sebzelerin bitki hastalık ve zararlılarının yayılmasına sebep olabilme potansiyel tehlikesinden haberdar olmalıdırlar. Bitki sağlığından daha fazla haberdar olmak ve ona dikkat etmek daha iyi bir hayatı sağlamak için esastır. Her birimiz bunları yaparak bitkilerimizin sağlığını korumada ve gıda güvenliğini sağlamada yardımcı olabiliriz. Bunların yanında, zararlı organizmaların özellikle ulusal ve uluslararası ticareti sırasında gözetim ve takip sistemi sürekli güncelleştirilerek 
geliştirilmelidir. Bu takip, bölgesel ve ulusal olduğu kadar uluslararası boyutta da olmalı ve sosyal ve diğer medyada yer bulmalıdır. $\mathrm{Bu}$ işlem gerçekleştirilirken biyolojik çeşitliliği de kapsayan biyolojik verilerin devamlılığı sağlanmalıdır.

Araştırma öncelikleri sürekli yenilenmelidir. Burada, zararlı ve hastalıkların tanısı, bitki patojenlerinin biyoloji, ekoloji, epidemiyolojisinin yanında konukçu ve vektörleri ile ilişkisi, konukçu dayanıklılığı, sürdürülebilir zararlı ve hastalık yönetiminde biyolojik ve kültürel mücadele stratejileri gibi tüm konular yer almalıdır. Üniversite ve araştırma kuruluşlarının faaliyetleri, resmi bitki sağlı̆̆1 yetkililerince yürütülen faaliyetleri ile uygun bir şekilde koordineli olmalıdır.

Bitki sağlığının desteklenmesinde en önemli olan şey araştırmalardaki ilerlemelerin daha iyi bir şekilde uygulamaya aktarılmasıdır. Burada da yenilik ve yönetmelikler devreye girer. Mücadele yaklaşımlarında pestisit kullanımını sınırlandırmak esas olmalıdır. Biotik streslere bitkilerin dayanıklılı̆̆ı esas olmalıdır. Yeniliklerin, eğitim ve politika belirleyicilerin donanımının desteklenmesi açısından araştırmalar çok önemlidir.

Sonuçta bitki sağlığı açısından araştırmalar ve uygulamaya aktarımı; teşhis teknolojilerinde, takipte ve iletişim metodolojilerinde hızlı ilerlemeyi sağlayacak; hali hazırdaki ve sonradan gelişecek olan tehditlerin anlaşılmasını artıracak ve de bitki sağlığının korunması, teşvik ve desteklenmesine yol açacaktır. Halk ve siyasiler tarafından görünürlüğü arttırılarak risk analizi ve yönetimi kolaylaştırılacaktır. Bitki sağlığını desteklemek, sürdürülebilirliğini devam ettirmek ve gelecek mücadelelere hazırlamak için yenilikçi yaklaşımların yürürlüğe konmasında ve tanımlanmasında olanaklar sağlanmalıdır.

\section{KAYNAKLAR}

Agrios G.N., 2005. Plant Pathology. Fifth Edition. Printed in the United States of America. pp, 922.

Burçak, A.A., Duru, A.U., Örnek, H., 2015. Bitki Koruma Ürünleri ve Pestisit Kalıntıları. ISBN: 978-605-9175-16-6. TAGEM Yayınları, Ezgi ofset matbaacılık, ANKARA. S. 164

Bruns, H. A., 2017. Southern Corn Leaf Blight:

A Story Worth Retelling. Agronomy Journal, 109 (4): 1-7.

Caciagli P., 2007. Survival of whiteflies during long-distance transportation of agricultural products and plants. In: The Tomato Yellow Leaf Curl Virus Disease: Management, Molecular Biology, Breeding for Resistance [ed. by Czosnek, H.]. Dordrecht, The Netherlands: Springer, $57-63$.

FAO, 2017. Plant health and food security. Published by FAO-IPPC (I7829EN/1/09.17)

FAO, 2019. Plant health and environmental protection. Published by FAO-IPPC (CA3279 EN/1/02.19). 